\title{
EDITORIAL
}

\section{Multi-disciplinary approaches to water systems: introduction to the special column}

\author{
Steven R. FASSNACHT $(\bowtie)^{1,2,3}$, Mingguo MA ${ }^{4}$ \\ 1 ESS-Watershed Science, Colorado State University, Fort Collins, CO 80523-1476, USA \\ 2 Cooperative Institute for Research in the Atmosphere, Fort Collins, CO 80523-1375, USA \\ 3 Natural Resources Ecology Laboratory, Fort Collins, CO 80523-1499, USA \\ 4 Research Base of Karst Eco-environments at Nanchuan in Chongqing, Ministry of Nature Resources, School of Geographical Sciences, \\ Southwest University, Chongqing 400715, China
}

(C) Higher Education Press 2020

\section{Introduction}

As the human population grows, the livelihoods and well-being of a significant portion of humanity will depend even more on the ability of freshwater ecosystems to provide essential services (Vörösmarty et al., 2010), which will require the maintenance of biodiversity in these freshwater systems (Dudgeon et al., 2006). There are many competing demands on the available water resources, such as potable water, fish and wildlife habitat, agriculture, industrial use, and recreation, that are driven by different sectors; even within a specific sector there can be diverging interests. For example, water management of the Upper Arkansas River in Colorado has been mandated by the 1949 Arkansas River Compact between the US states of Colorado and Kansas which has led to stream-aquifer issues (Taylor and Luckey, 1974), water transfers from agriculture to urban (Howe et al., 1990), and competing recreational uses (Wollmuth et al., 1985; Arkansas Basin Roundtable, 2017). The recent Upper Arkansas Voluntary Flow Management Program tries to balance many users, including recreation by kayakers and rafters who want to maintain streamflow (at the Wellsville gauge) at or greater than $20 \mathrm{~m}^{3} / \mathrm{s}$ as well as anglers who want lower flows in the range of 7 to $11 \mathrm{~m}^{3} / \mathrm{s}$ to maintain fish habitat (Arkansas Basin Roundtable, 2017).

A variety of strategies have been used in an attempt to bridge disciplines, including focusing research on change in hydrology and society (Montanari et al., 2013), socioeconomic vulnerability and adaptation to hydrometeorological extremes (Drobinski et al., 2014), using local, traditional, and indigenous knowledge to understand natural systems (Berkes, 1993), combining data sets from social and physical systems (Fassnacht et al., 2018a; Laituri, P256-P267), and applying poetic inquiry with poetry-based approaches (Fernández-Giménez et al., 2019a). However, there is often a mismatch of understanding between different disciplines (Scholten et al., 2007), and research from various perspectives often use varying terminology and rely on different data sets (Fernández-Giménez et al., 2019b). Water problems are global and we need new tools and approaches to address them (Huntington, 2000; Kreibich et al., 2017, Krueger et al., 2016). The different disciplines, i.e., social, ecological, and physical (hydrological), have traditionally been examined separately.

The social, ecological, and physical/hydrological perspectives of a system (Vollmer et al., 2018) can be viewed as semi-transparent lenses with the depth of color illustrating the importance of each lens (Fig. 1). In this example, as we move upstream (from Figs. 1(a) to 1(b) to 1(c)), the direct social importance is conceptualized to become less with the red circle becoming lighter as the hydrological importance becomes greater with the blue circle becoming darker. The intersection of the circles shows the color of the new interdisciplinary lens. Within each lens, there are a number of attributes that combine to give the lens its depth of color, and these themselves can be competing. Within each lens (Fig. 1), there are a number of attributes that combine to give the lens its depth of color, and these themselves can be competing. What some may call multi-disciplinary may be different subjects within the same disciplines, or

Received June 5, 2020

E-mail: Steven.Fassnacht@colostate.edu 
using the lens concept, different shades within one lens (Fig. 2). Further, since "the limits of [our] language mean the limits of [our] world" (Wittgenstein, 1922), research should consider expanding language and translation (Warden et al., 2020) to help combine disciplines and more deeply explores across sub-disciplines to better study and understand water systems.

This special column of Frontiers of Earth Science started as a symposium on Multi-disciplinary Approaches to Water Systems that was held at the University of Jinan in Shandong, China on October 31st, 2017. The focus was methods to assess water systems, with an emphasis on water resources and environmental sustainability in any part of the globe with a physical, ecological, or social science perspective, or any combination thereof. The goals of this special column were to provide insight into the variety of methods that are being used to describe water systems, and to illustrate the use of more than one method and/or non-traditional methods to quantify and describe water resources and water systems. One invited paper (Laituri, P256-P267) and five regular papers appear in the issue. The papers are divided into social-physical and intra-disciplinary topics. The first special issue on the theme of Water and Environmental Sustainability focused on Headwaters Regions and appeared in 2017 (Fassnacht et al., 2017). The second special column on the theme of Water and Environmental Sustainability focused on Uncertainty in Water Resources and appeared in 2018 (Fassnacht et al., 2018b).

\section{Overview of special issue papers}

This special column begins with a concept paper (Laituri, P256-P267) that examines the implementation of innovative water management strategies in three rapidly urbanizing river basins: the Nairobi River in Kenya, the Citarum River in Indonesia, and the Addis Ababa River in Ethiopia. It uses the hydrosocial cycle as a framework to investigate the social, technical and physical aspects of water flows related to improving water security. Water justice issues of gender and inequity are discussed since technical requirements, restoration management, and engineering solutions often do not consider these inequalities in implementing largescale water management strategies. The three river basin projects are compared in the context of the hydrosocial cycle framework to explore the social power and structure, technology and infrastructure, and the materiality of water in each location. The paper provides recommendations to improve and address holistic water management for large-scale technical projects to increase community engagement.

The Integrated Water Resources Management (IWRM) approach was adopted in the 1990s by the Chinese government to combat the degradation of water and ecological systems throughout its rural regions, such as northwestern China where there have been tension between economic growth and ecological crises. While the IWRM approach has assisted in reducing desertification, water shortage, and ecological deterioration, its top-down implementation relies on infrastructure heavy and technocratic solutions to govern water demand and has resulted in important limitations and obstacles that impede optimal water management. Mao et al. (P268-P285) examines the historical, social, political, and economic processes that have created the IWRM shortcomings and similar to Laituri (P256-P267) recommends a more holistic, socio-political perspective for water management that considers the state-society dynamics inherent in water governance in rural China.

Herders were surveyed by Tumenjargal et al. (P286-P297) to identify their observations of changes in climate extremes for two soums (counties) of the Khangai Mountain region of central Mongolia. The three northerly stations showed the same trends in climate extremes, while the southern-most station had similar trends for some variables and opposite trends for others, mostly like due to the effects of record length or localized conditions. The herders' indigenous knowledge of changes in climate extremes mostly aligned with the station-based analyses of change. Temperatures were warming with more warm days and nights at all stations. There were fewer cool days and nights observed at the mountain stations both in the summer and winter, yet more cool days and nights were observed in the winter at the desert steppe station. Almost all of these trends were significant, and many were reflected in the observations of change made by herders. They observed a general increase in frequency of extreme precipitation, but this increase was not captured by station record trend analysis. Therefore, it is recommended that indigenous knowledge from herders be combined with station record analysis to provide more holistic information about climate extremes and changes using different approaches.

Three papers focused on intra-disciplinary examinations of water systems. The City of Jinan in Shandong province of eastern China is known as Spring City due to its abundance of artesian karst springs (Wu and Xu, 2005). The heavily sediment-laden Yellow River flows through Jinan and this influences the groundwater, especially the managed aquifer recharge system that the supplies urban water and spring water. The next two paper address these sediment issues. Li et al. (P298-P305) describes a series of laboratory experiments to assess the development of a new recharge well. Such wells are used as important recharge facilities for underground reservoirs and are 
commonly installed in river channels and irrigation canals on the Shandong Peninsula, China. The experimentation was to assess the gradually decrease in recharge capacity. A round empty core infiltration and anti-filtration recharge well and laboratory recharge test equipment were evaluated. Scale 1:25 models were created of a recharge pond, a round empty core recharge wellhead, and an artificial recharge well. Results showed that compared with the existing anti-filtration recharge well, the new round empty core infiltration and anti-filtration recharge well had stronger antideposition and anti-scouring properties, and the single-well recharge quantity increased by over $400 \%$.

The paper by Zheng et al. (P306-P314) examines the physical clogging during of sand gravel infiltration in the Yufuhe River due to the heavy sediment loads of the Yellow River. The authors use a laboratory sand column experiment with a heterogeneous sand-gravel mixture under a variety of conditions to perform physical clogging tests with different hydraulic head and inflow suspension concentrations. The rate of clogging of the filtration system was a function of the suspended particles, simulated as part of the Yellow River inflow, and the rate of recharge, based on the hydraulic head. Correlations were found, but the medium-sized substrate showed the greatest movement. Field observations were included to illustrate the improved recharge water quality from the filtration.

Nineteen indices from 458 snow telemetry (SNOTEL) stations for the period 1982 through 2012 were used by Fassnacht and López-Moreno (P315-P325) to describe the annual temporal evolution in snow water equivalent (SWE) accumulation and ablation across the Western United States. The trends in these annual indices were computed over the time period for each station using the Theil-Sen slope and then were clustered into four groups to determine the spatiotemporal dynamics of SWE. Results show that SNOTEL stations can be grouped in four clusters according to the observed trends in snow indices, with one cluster located mostly in the eastern and south-eastern parts of the study area and exhibiting a generalized decrease in the indices related with peak SWE and snow accumulation and a negative trend in precipitation and an increase in temperature. Another cluster consists mostly of stations in the north and north-west of the study area and shows an almost opposite pattern to the first cluster, due to

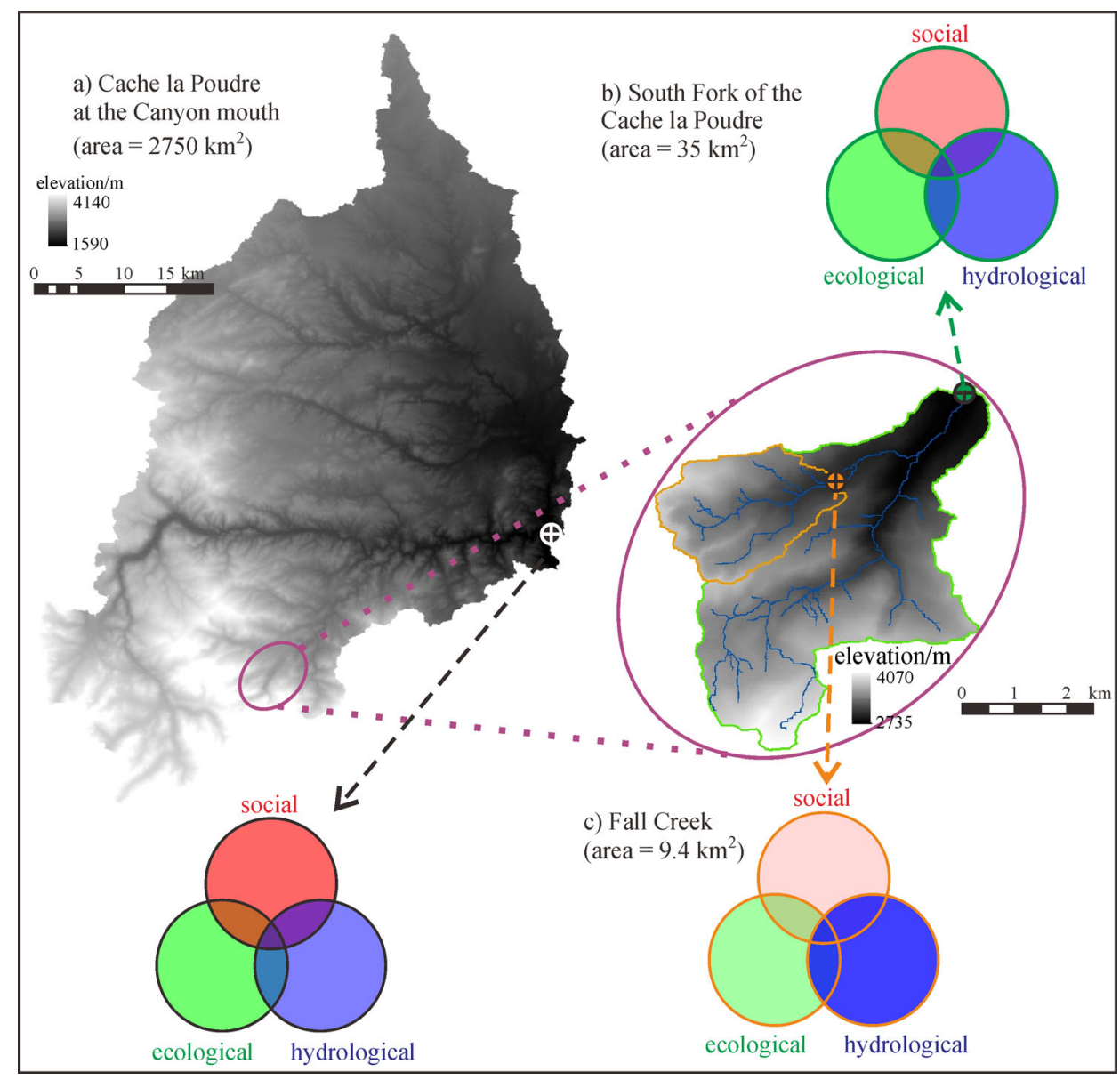

Fig. 1 Example of the relative importance (depth of color) for the three perspectives (social in red, ecological in green, physical/ hydrological in blue) applied to a) the Cache la Poudre River (CLP) at the Canyon mouth near Fort Collins, b) the South Fork (SF) tributary of the CLP, and c) Fall Creek, a tributary to the SF of the CLP. 
months with positive trends and a more moderate increase of temperature. Stations grouped in clusters 2 and 3 appear mixed with clusters 1 and 4 ; in general they show very little trends in the snow indices.

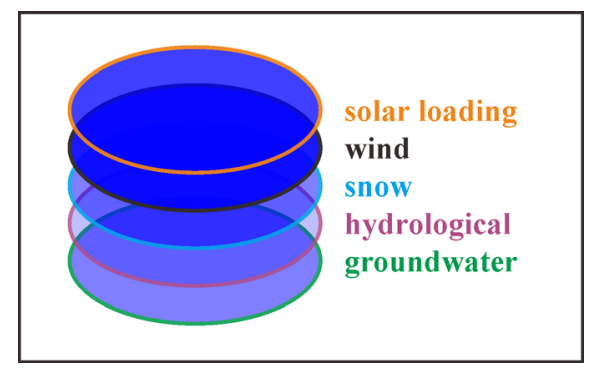

Fig. 2 Example of shades or sub-disciplines within the hydrological lens or discipline of Fig. 1.

Acknowledgements We thank the Confucius Institute Headquarters (Hanban) for supporting the Colorado State University Confucius Institute and the Water and Environmental Sustainability symposium series, plus Dr. Xiaoyu Chen and Professor Qing Zhao of East China Normal University for their help in coordinating this special column.

\section{References}

Arkansas Basin Roundtable (2017). Upper Arkansas Voluntary Flow Management Program. Arkansas Basin Roundtable, May 10, 2017, Available at www.arkansasbasin.com/uploads/2/7/1/8/27188421/2017-05-10_upper_ark_voluntary_flow_mgmt_program.pdf

Berkes F (1993). Traditional ecological knowledge in perspective. In: J T Inglis, ed. Traditional Ecological Knowledge: Concepts and Cases. Ottawa: International Program on Traditional Ecological Knowledge and International Development Research Centre, 1-10

Drobinski P, Ducrocq V, Alpert P, Anagnostou E, Béranger K, Borga M, Braud I, Chanzy A, Davolio S, Delrieu G, Estournel C, Boubrahmi N F, Font J, Grubišić V, Gualdi S, Homar V, Ivančan-Picek B, Kottmeier C, Kotroni V, Lagouvardos K, Lionello P, Llasat M C, Ludwig W, Lutoff C, Mariotti A, Richard E, Romero R, Rotunno R, Roussot O, Ruin I, Somot S, Taupier-Letage I, Tintore J, Uijlenhoet R, Wernli H (2014). HyMeX: a 10-year multidisciplinary program on the mediterranean water cycle. Bull Am Meteorol Soc, 95(7): 1063-1082

Dudgeon D, Arthington A H, Gessner M O, Kawabata Z, Knowler D J, Lévêque C, Naiman R J, Prieur-Richard A H, Soto D, Stiassny M L J, Sullivan C A (2006). Freshwater biodiversity: importance, threats, status and conservation challenges. Biol Rev Camb Philos Soc, 81(2): 163-182

Fassnacht S R, Webb R W, Sanford W E (2017). Headwater regions-physical, ecological, and social approaches to understand these areas: introduction to the special issue papers. Front Earth Sci, 11(3): 443-446

Fassnacht S R, Allegretti A M, Venable N B H, Fernández-Giménez M E, Tumenjargal S, Kappas M, Laituri M J, Batbuyan B, Pfohl A K D (2018a). Merging indigenous knowledge systems and station observations to estimate the uncertainty of precipitation change in central Mongolia. Hydrology, 5(3): 46

Fassnacht S R, Webb R W, Ma M (2018b). Uncertainty in water resources: introduction to the special column. Front Earth Sci, 12(4): 649-652

Fernández-Giménez M E, Jennings L B, Wilmer H (2019a). Poetic inquiry as a research and engagement method in natural resource science. Soc Nat Resour, 32(10): 1080-1091

Fernández-Giménez M E, Angerer J, Batkhishig B, Batbuyan B, Fassnacht S R, Chantsallkham J, Khishigbayar J, Laituri M J, Mendezona Allegretti A, Reid R S Thompson J Tungalag Ulambayar, Venable N B H (2019b). Sustaining interdisciplinary collaboration across continents and cultures: lessons from the Mongolian rangelands and resilience project. In: S.G. Perz, ed. Collaboration Across Boundaries for Social-Ecological Systems Science Experiences Around the World, Palgrave Macmillan. Cham: Springer Nature, 185-225

Howe C W, Lazo J K, Weber K R (1990). The economic impacts of agriculture-to-urban water transfers on the area of origin: a case study of the Arkansas River Valley in Colorado. Am J Agric Econ, 72(5): 1200-1204

Huntington H (2000). Using Traditional Ecological Knowledge in science methods and applications. Ecol Appl, 10(5): 1270-1274

Kreibich H, Krueger T, Van Loon A, Mejia A, Liu J, McMillan H, Castellarin A (2017). Scientific debate of Panta Rhei research-how to advance our knowledge of changes in hydrology and society? Hydrol Sci J, 62(3): 331-333

Krueger T, Maynard C, Carr G, Bruns A, Mueller E N, Lane S (2016). A transdisciplinary account of water research. WIREs Water, 3(3): 369-389 Montanari A, Young G, Savenije H H G, Hughes D, Wagener T, Ren L L, Koutsoyiannis D, Cudennec C, Toth E, Grimaldi S, Blöschl G, Sivapalan M, Beven K, Gupta H, Hipsey M, Schaefli B, Arheimer B, Boegh E, Schymanski S J, Di Baldassarre G, Yu B, Hubert P, Huang Y, Schumann A, Post D A, Srinivasan V, Harman C, Thompson S, Rogger M, Viglione A, McMillan H, Characklis G, Pang Z, Belyaev V (2013). "Panta rheieverything flows": change in hydrology and society-the IAHS scientific decade 2013-2022. Hydrol Sci J, 58(6): 1256-1275

Scholten H, Kassahun A, Refsgaard J C, Kargas T, Gavardinas C, Beulens A J M (2007). A methodology to support multidisciplinary model-based water management. Environ Model Softw, 22(5): 743-759 
Taylor O J, Luckey R R (1974). Water-management studies of a stream-aquifer system, Arkansas River Valley, Colorado. Ground Water, 12(1): 22-38 Vollmer D, Shaad K, Souter N J, Farrell T, Dudgeon D, Sullivan C A, Fauconnier I, MacDonald G M, McCartney M P, Power A G, McNally A, Andelman S J, Capon T, Devineni N, Apirumanekul C, Ng C N, Rebecca Shaw M, Wang R Y, Lai C, Wang Z, Regan H M (2018). Integrating the social, hydrological and ecological dimensions of freshwater health: The Freshwater Health Index. Sci Total Environ, 627: 304-313

Vörösmarty C J, McIntyre P B, Gessner M O, Dudgeon D, Prusevich A, Green P, Glidden S, Bunn S E, Sullivan C A, Liermann C R, Davies P M (2010). Global threats to human water security and river biodiversity. Nature, 467(7315): 555-561

Warden M C, Fassnacht S R, Carlyon J E (2020). The hydro-social implications of water metaphors in poetry: transmogrification challenges in an example from the medieval Spanish romancero. Denver: Colorado Water

Wittgenstein L (1922). Tractatus Logico-Philosophicus-Logisch-philosophische Abhandlung. London: Kegan Paul

Wollmuth D C, Schomaker J H, Merriam L C (1985). River recreation experience opportunities in two Recreation Opportunity Spectrum (ROS) classes. J Am Water Resour Assoc, 21(5): 851-857

Wu Q, Xu H (2005). A three-dimensional model and its potential application to spring protection. Environ Geol, 48(4-5): 551-558

\section{Guest Editors}

Dr. Steven R. Fassnacht is a professor of Watershed Science, Department of Ecosystem and Sustainability, Colorado State University. He received his Ph.D. in Civil Engineering from the University of Waterloo, Canada in 2000 after receiving a B.A.Sc. (Civil Engineering-Water Resources) in 1992 and M.A.Sc. (Civil Engineering) in 1995 from the same institution. From 2000 to 2002 he was a Research Associate in the Hydrology and Water Resources Department at the University of Arizona. Since then he has been faculty at Colorado State University. He is currently a Research Fellow with the Cooperative Institute for Research in the Atmosphere, a Senior Research Scientist in the Natural Resources Ecology Laboratory and the Associate Director of the Vertically Integrated Projects Program at CSU. He is also the Water and Environmental Sustainability Coordinator for the Confucius Institute at Colorado State University. Over the 2016-2017 academic year, he was a visiting professor in the Cartography, GIS \& Remote Sensing Department of the Geography Institute at Georg-August-Universität Göttingen in Germany. Dr. Fassnacht's research interests include improving our understanding of snow and cold land hydrological processes into different type of models, the spatial and temporal variability of earth system properties, and the impacts of a changing climate on water resources. To examine how a changing climate affects water resources, his work is integrating human observations of change with station and geospatial information.

Dr. Mingguo Ma is a professor of Land Surface Process Monitoring and Simulation, School of Geographical Sciences, Southwest University. He received his B.Sc. degree (Economic Geography and Urban and Rural Regional Planning) in 1998 from Lanzhou University, China, and the Ph.D. degree (Cartography and Geographical Information Systems) in 2003 from Cold and Arid Regions Environmental and Engineering Research Institute (CAREERI), Chinese Academy of Sciences (CAS). He had carried out the cooperation research and post-doctoral fellowship in 2004 from Flemish Institute for Technological Research (Vito) Center for Remote Sensing and Atmospheric Processes (TAP), Belgium. He had worked as a professor at the Laboratory of Remote Sensing and Geospatial Science, CAREERI, CAS from 2009 to 2014. His main research interests have been in ecological remote sensing and land surface process remote sensing. He joined two famous comprehensive experiments at a watershed scale, Watershed Airborne Telemetry Experimental Research (WATER) and Heihe Watershed Airborne Telemetry Experimental Research (HiWATER), and organized the ground-based synchronous and intensive observations. Recently his work mainly focuses on the land surface process observation and analysis using multi-scale observation system and monitoring and simulation using the long time series remote sensing data in southwest China. 